\title{
Biocidal potential of Eugenia pyriformis essential oil in the control of Rhipicephalus (Boophilus) microplus in the free-living cycle ${ }^{1}$
}

\author{
Jaqueline P. Medeiros² (D), Wanessa C. Bortollucci², Eloisa S. Silva ${ }^{2}$, \\ Herika L.M. Oliveira ${ }^{2}$, Caio F.A.A. Campo ${ }^{2}$, José Eduardo Gonçalves ${ }^{2,3}$, \\ Ranulfo P. Junior ${ }^{4}$ and Zilda Cristiani Gazim ${ }^{2 *}$
}

\begin{abstract}
Medeiros J.P., Bortollucci W.C., Silva E.S., Oliveira H.L.M., Campos C.F.A.A., Gonçalves J.E., Piau Junior R. \& Gazim Z.C. 2019. Biocidal potential of Eugenia pyriformis essential oil in the control of Rhipicephalus (Boophilus) microplus in the free-living cycle. Pesquisa Veterinária Brasileira 39(11):879-888. Graduate Program in Biotechnology applied to Agriculture, Universidade Paranaense, Praça Mascarenhas de Moraes 4282, Umuarama, PR 87502-210, Brazil. E-mail: cristianigazim@prof.unipar.br

Brazil has one of the largest commercial cattle herds in the world, which naturally coexist with an enormous number of parasitic species. Southern cattle tick, Rhipicephalus (Boophilus) microplus, is among these species, interfering with animal productivity and causing losses to the beef and dairy cattle sector. The use of chemical acaricides in the control of this mite has resulted in the emergence of resistant populations. In this sense, alternative control measures using plants as sources of botanical acaricides have shown to be effective. Eugenia pyriformis Cambess is a Brazilian plant with antioxidant and antimicrobial activity; however, there are no reports on its acaricidal activity in the literature. The present study aimed to evaluate the acaricidal and larvicidal potential of E. pyriformis leaf essential oil (EO) on southern cattle tick at different stages of the reproductive cycle. E. pyriformis leaves were collected and dried, and had their EO extracted by hydrodistillation ( $3 \mathrm{~h}$ ) using a modified Clevenger apparatus. Chemical analysis was performed by gas chromatography coupled with mass spectrometry (GC/MS), and 32 compounds belonging to the sesquiterpene class were identified: hydrocarbons $(17.98 \%)$ and oxygenated forms (81.96\%), with spathulenol (43.65\%) and caryophyllene oxide $(12.17 \%)$ as the most common. The EO was evaluated by the Adult Immersion Test at the concentrations $(500.00$ to $3.12 \mathrm{mg} / \mathrm{mL})$ in which the following parameters were measured: mortality of females (\%), hatchability of eggs (\%), and product efficiency (\%). Larvae were assessed by the Larval Packet Test at concentrations ranging from 25.00 to $0.00004 \mathrm{mg} / \mathrm{mL}$. Lethal concentrations (LC) required for killing 50 and $99.9 \%$ of adult females and larvae were determined using Probit analysis. $\mathrm{LC}_{50}$ and $\mathrm{LC}_{99.9}$ of $\mathrm{EO}$ were 0.06 and $24.60 \mathrm{mg} / \mathrm{mL}$ and $1,208.80$ and $2,538 \mathrm{mg} / \mathrm{mL}$ for larvae and adult females, respectively. Action of the EO in the free-living cycle of $R$. (B.) microplus larvae was another parameter assessed. To this end, the larvae were deposited in pots containing Brachiaria decumbens and, after migration to the leaf apex, a solution containing $\mathrm{LC}_{99.9}(24.60 \mathrm{mg} / \mathrm{mL})$ of the EO was sprayed. After $24 \mathrm{~h}$, $72.25 \%$ of the larvae had died, indicating stability of the EO when subjected to uncontrolled temperature and humidity conditions. The mechanism of action through which the EO killed the larvae and adult females was investigated by the Bioautographic Method, which showed
\end{abstract}

\footnotetext{
${ }^{1}$ Received on June 18, 2019.

Accepted for publication on July 12, 2019.

${ }^{2}$ Graduate Program in Biotechnology applied to Agriculture, Universidade Paranaense (Unipar), Praça Mascarenhas de Moraes 4282, Umuarama, PR 87502-210, Brazil. E-mails: jaquepavel@hotmail.com,wanessa.bortolucci@edu. unipar.br, eloisa.s@edu.unipar.br, herika_line@hotmail.com; *Corresponding author: cristianigazim@prof.unipar.br
}

\footnotetext{
Master of Science in Clean Technology, Instituto Cesumar de Ciência, Tecnologia e Inovação, Centro Universitário de Maringá, Avenida Guedner 1610, Jardim Aclimação, Maringá, PR 87050-900, Brazil. E-mails: jose. goncalves@unicesumar.edu.br, caiofaac@hotmail.com

${ }^{4}$ Graduate Program in Animal Science, Universidade Paranaense (Unipar), Praça Mascarenhas de Moraes 4282, Umuarama, PR 87502-210. E-mail: piau@prof.unipar.br
} 
inhibition of $3.15 \mathrm{mg} / \mathrm{mL}$ of the EO on the acetylcholinesterase (AChE) enzyme. The results found in the present experiment indicate that E. pyriformis essential oil is an alternative in the control of southern cattle tick in the larval (parasitic) and free-living cycle (non-parasitic) stages under field conditions.

INDEX TERMS: Biocidal, Eugenia pyriformis, essential oil, Rhipicephalus (Boophilus) microplus, free-living cycle, "uvaia", acaricide, larvicide, spathulenol, caryophyllene oxide, acetylcholinesterase, alternative acaricides, tick.

RESUMO.- [Potencial biocida do óleo essencial de Eugenia pyriformis Cambess no controle de Rhipicephalus (Boophilus) microplus no ciclo de vida livre.] O Brasil dispõe de um dos maiores rebanhos bovinos comerciais do mundo, sendo natural que junto a esse rebanho, coexista uma enorme quantidade de espécies parasitárias; dentre estes o carrapato Rhipicephalus (Boophilus) microplus que interfere na produtividade animal, causando prejuízos à pecuária de corte e leite. A utilização de acaricidas químicos no controle deste ácaro tem causado o surgimento de populações resistentes e neste sentido, controles alternativos utilizando plantas como fontes de acaricidas botânicos têm se mostrado eficazes. Eugenia pyriformis Cambess é uma planta brasileira com atividades antioxidante e antimicrobiana, entretanto não há relatos da atividade acaricida. 0 objetivo do presente estudo consistiu na avaliação do potencial acaricida e larvicida do óleo essencial das folhas de E. pyriformis sobre o carrapato bovino nos diferentes estágios do ciclo reprodutivo. As folhas foram coletadas, secas e o OE extraído por hidrodestilação (3 horas) em aparelho Clevenger modificado. A análise química foi realizada por cromatografia gasosa acoplada à espectrometria de massas (CG/EM) sendo identificados 32 compostos, pertencentes à classe sesquiterpenos: hidrocarbonetos (17.98\%) e oxigenados (81.96\%); tendo como majoritários o spathulenol $(43,65 \%)$ e caryophylene oxide $(12,17 \%)$. 0 OE foi avaliado pelo teste de imersão de adultos nas concentrações $(500,00$ a $3,12 \mathrm{mg} / \mathrm{mL})$ onde foram mensurados os parâmetros: mortalidade das fêmeas (\%), eclodibilidade dos ovos (\%) e eficiência do produto (\%). As larvas foram avaliadas pelo teste de imersão larval (Larval Packet Test) nas concentrações que variaram de 25,00 a $0,00004 \mathrm{mg} / \mathrm{mL}$. Foram determinadas as concentrações letais (CLs) necessárias para matar 50 e 99,9\% das fêmeas adultas e das larvas utilizando a análise de Probitos. As $\mathrm{CL}_{50}$ e $\mathrm{CL}_{90,9}$ do OE foram $(0,06$ e $24,60 \mathrm{mg} / \mathrm{mL})$ para as larvas e $(1.208,80$ e $2.538 \mathrm{mg} / \mathrm{mL})$ para as fêmeas adultas, respectivamente. Outro parâmetro avaliado em nossa pesquisa foi mensurar a ação do OE no ciclo de vida livre das larvas de R. (B.) microplus; onde as larvas foram depositadas em vasos com Brachiaria decumbens e após migração destas para o ápice das folhas, foi aspergido solução contendo a $\mathrm{CL}_{99,9}(24,60 \mathrm{mg} / \mathrm{mL})$ do OE. Após 24 horas, $72,25 \%$ das larvas morreram indicando que houve estabilidade do $\mathrm{OE}$ quando submetido a condições de temperatura e umidade não controladas. 0 mecanismo de ação pelo qual o OE matou as larvas e fêmeas adultas foi investigado pelo método bioautográfico, indicando uma inibição de $3,15 \mathrm{mg} / \mathrm{mL}$ do óleo essencial sobre a enzima acetilcolinesterase (AChE). Os resultados encontrados no presente experimento indicaram que o óleo essencial de E. pyriformis é uma alternativa no controle do carrapato bovino no estágio larval (parasitário) e no ciclo de vida livre (estágio não parasitário) em condições de campo.
TERMOS DE INDEXAÇ̃̃o: Biocida, óleo essencial, Eugenia pyriformis, Rhipicephalus (Boophilus) microplus, ciclo de vida livre, uvaia, acaricida, larvicida, spathulenol, caryophyllene oxide, acetilcolinesterase, alternative acaricida, carrapato.

\section{INTRODUCTION}

Livestock is one of the most important activities in Brazilian agribusiness, as the country has one of the largest commercial cattle herds and is the second largest producer and the largest exporter of beef in the world (De Carvalho \& De Zen 2017). However, profitability of the livestock activity is significantly diminished by the effects of parasites affecting cattle. Southern cattle tick, Rhipicephalus (Boophilus) microplus, is among these parasites (Ramírez et al. 2016). It is an ectoparasite with a parasitic life cycle of 21 days in live host, and a free-living cycle of up to 300 days in pasture without live host (Pereira et al. 2015). This tick causes losses in the order of billions of dollars per year in Brazil (Grisi et al. 2014) as a result of reduced beef and milk production, falling birth rates, increased mortality, devaluation of leather, transmission of important pathogens, and spending on an attempt to control it (Campos et al. 2012).

Control of this tick is based on the use of chemicals such as organophosphates, carbamates, amidines, synthetic pyrethroids, fluaruzon, and lactone macrolides (Mendes et al. 2013). One of the problems of the continuous use of chemicals in the control of ticks is the residues left in the body and milk of treated animals, presenting a long period of action. In humans, these residues can cause neurotoxic disorders, endocrine system disorders, allergies, cough, and abnormalities of lung function (Ferrarini et al.2008). Thus, there is a demand for the implementation of research and technologies that promote sustainable development with the use of natural products (Zaman et al. 2012) that have acaricidal properties, which may be an alternative to control ticks with lesser environmental impact (Chagas et al. 2002).

There are several species of plants in the Brazilian flora, or cultivated in the country, that are used in southern cattle tick control programs in an attempt to reduce the use of conventional products. Citronella (Cymbopogon nardus), neem (Azadirachta indica), andiroba (Carapa guianensis), tobacco (Nicotiana tabacum), lemongrass (Cymbopogon citratus), eucalyptus (Eucalyptus spp. and Corymbia) and others comprise the group of herbal medicines with acaricidal efficacy (Alves et al. 2014).

Research in this area is promising, as evidenced by the several studies conducted on this theme. Clemente et al. (2010) observed the acaricidal activity of Eucalyptus citriodora and Cymbopogon nardu oils on ticks. De Souza et al. (2012) observed a tendency to low mammalian toxicity, rapid degradation and slow resistance development in plant-borne acaricides. Gomes et al. (2012) evaluated the effect of Lippia sidoides oil 
on $R$. (B.) microplus larvae and females. De Monteiro et al. (2012) and Valente et al. (2014) confirmed the acaricidal activity of myrtaceae on larvae and females of $R$. microplus. De Assis et al. (2015) demonstrated the acaricidal activity of Baccharis dracunculifolia essential oil on non-engorged larvae and engorged females of $R$. microplus.

However, there are no reports of control studies addressing the southern cattle tick R. (B.) microplus using Eugenia pyriformis Cambess essential oil (EO).

E. pyriformis species belongs to family Myrtaceae, a plant commonly found in the states of São Paulo, Paraná, Santa Catarina, and Rio Grande do Sul, known by the popular names of "uvaia,' 'uvaieira", or field bush (Armstrong et al. 2012). This plant is a 6-13m tall tree with brown, erect trunk and rounded crown. Flowering occurs from August to September with fruit ripening between November and December. The genus to which it belongs presents a large number of species in Brazil, which are known for the production of essential oils (Stieven et al. 2009). Research has shown that E. pyriformis EO has acaricidal (De Assis et al. 2011), antimicrobial, antioxidant (Stieven et al. 2009), and antifungal (Souza 2013) potential against Tyrophagus putrescentiae and Suidasia pontifica Oudemans. Studies conducted with the fruits of "uvaia" revealed the presence of total flavonoids and phenolic compounds, highlighting the antioxidant potential of this species (Silva et al. 2018, Da Silva et al. 2019). However, there are no reports in the literature on the application of E. pyriformis oil in the control of southern cattle tick, which led our research group to evaluate the chemical composition of E. pyriformis leaf $\mathrm{EO}$ and its effectiveness in the control of this pathogen in vitro and ex situ (free-living cycle), as well as to measure the acaricidal activity of this EO in application under semi-natural conditions for the control of $R$. (B.) microplus larvae.

\section{MATERIALS AND METHODS}

Data on plant material, soil analysis, temperature $\left({ }^{\circ} \mathrm{C}\right)$, rainfall $(\mathbf{m m})$ and relative humidity (\%). Eugenia pyriformis Cambess leaves were collected in the municipality of Mangueirinha, southwestern Paraná state, Brazil (2556'28” S; 52¹0’32” W) 921m a.s.l. from January to August 2015. During this period, data on temperature $\left({ }^{\circ} \mathrm{C}\right)$, rainfall $(\mathrm{mm})$ and relative humidity $(\%)$ were obtained from the "Secretaria Estadual de Agricultura e Abastecimento" (SEAB) of the aforementioned municipality. The plant was identified and deposited at the Herbarium of the "Universidade Estadual de Maringá" (UEM) under no. 30.713. This species is registered in the National System of Genetic Heritage Management and Associated Traditional Knowledge (SisGen) under no. A06F4D8. The soil in the location where the Eugenia pyriformis leaves were collected at $0-20 \mathrm{~cm}$ depth in different points was analyzed at the Santa Rita Soil Analysis Laboratory in the municipality of Mamborê, Paraná state.

Extraction of Eugenia pyriformis leaf essential oil (E0). The leaves were dried at room temperature, sectioned in a milling processor, and hydrodistilled using the modified Clevenger apparatus. The plant-to-water ratio was $300 \mathrm{~g}$ fragmented leaves to $3000 \mathrm{~mL}$ distilled water. Hydrodistillation was performed for $3 \mathrm{~h}$, and the oil was removed with $n$-hexane, filtered with anhydrous sodium sulfate $\left(\mathrm{Na}_{2} \mathrm{SO}_{4}\right)$ (Simões \& Spitzer 2002), stored in amber flasks, and kept under refrigeration at $4^{\circ} \mathrm{C}($ Omolo et al. 2004) for complete solvent evaporation. EO yield was determined by the dry leaf mass to EO mass $(\%)$ ratio.
Physical and chemical indices of Eugenia pyriformis leaf EO. Relative density was obtained by the mass-to-volume ratio at $20^{\circ} \mathrm{C}$, and determined according to the technique described by the Farmacopeia Brasileira (1988). The refractive index was determined using an RL-3 Abbe refractometer (Warsaw, Poland) (Farmacopeia Brasileira 1988).

Chemical characterization. Chemical identification of the EO was carried out by GC-MS using an Agilent 7890B Gas Chromatograph coupled with an Agilent 5977 A MSD Mass Spectrometer and an Agilent HP-5ms UI fused silica capillary $(30 \times 250 \mu \mathrm{m} \times 0.25 \mu \mathrm{m}$; Agilent Technologies), with initial oven temperature of $50^{\circ} \mathrm{C}(2 \mathrm{~min})$, followed by an increase to $60^{\circ} \mathrm{C}$ at $5^{\circ} \mathrm{C} / \mathrm{min}$ for $1 \mathrm{~min}$, an increase to $250^{\circ} \mathrm{C}$ at $5^{\circ} \mathrm{C} / \mathrm{min}$ for $15 \mathrm{~min}$ and, finally, an increase to $300^{\circ} \mathrm{C}$ at $50^{\circ} \mathrm{C} / \mathrm{min}$ for $1 \mathrm{~min}$. Helium was utilized as the carrier gas at the linear speed of $1 \mathrm{~mL} / \mathrm{min}$ up to $300^{\circ} \mathrm{C}$ and pressure release of $56 \mathrm{kPa}$. The injector temperature was $250^{\circ} \mathrm{C}$; injection volume was $1 \mu \mathrm{L}$; injection occurred in split mode (20:1). The temperatures of the transfer line, ion source, and quadrupole were 240,230 and $150^{\circ} \mathrm{C}$, respectively. The MS detection system was used in scan mode at the mass-to-charge ratio $(\mathrm{m} / \mathrm{z})$ of 40-550 with solvent delay of $3 \mathrm{~min}$. The compounds were identified by comparing the mass spectra found in NIST Mass Spectral Library (NIST 11.0) and the retention indices (RI) obtained by a homologous series of $n$-alkane standard (C7-C28) (Adams 2012).

Essential oil activity on Rhipicephalus (Boophilus) microplus. Acaricidal activity of "uvaia" EO was determined by the adult immersion test (AIT) (Drummond et al. 1973) and the larval packet test (LPT), recommended by the Food and Agriculture Organization (FAO 2004), whereas larvicidal activity was verified in the free-living cycle (Araújo et al. 2015).

Adult immersion test (AIT). A total of 360 Rhipicephalus (Boophilus) microplus female ticks with maximum engorgement were collected from dairy cattle in a farm in the municipality of Umuarama, Paraná state, Brazil. Then E. pyriformis EO solutions were prepared at the following concentrations: 500.00, 400.00, 300.00, $200.00,100.00,50.00,25.00,12.50,6.25$ and $3.12 \mathrm{mg} / \mathrm{mL}$. A $2 \%$ (v/v) aqueous polysorbate-80) solution was used as EO emulsifier. The negative control was a $2 \%(\mathrm{v} / \mathrm{v}$ ) aqueous polysorbate- 80 solution, whereas the positive control was a $0.125 \%$ commercial solution containing $15 \%$ cypermethrin, $25 \%$ chlorpyrifos and $1 \%$ citronellal. Subsequently, the ticks cleaned with water and selected based on normal appearance and motility, body integrity, and maximum engorgement (Leite et al. 1995). The AIT was performed according to Drummond et al. (1973). From the data obtained (tick mass, egg mass, and egg hatching rate), reproductive efficiency (RE) and product efficiency (PE) were calculated according to Equations 1 and 2, respectively (Drummond et al. 1973).

$$
\begin{gathered}
R E=\frac{\text { egg mass }(g) \times \text { hatching rate }(\%) \times 20.000}{\text { tick mass }(g)} \\
R E=\frac{\text { negative Control Group } R E-\text { Treated Group } R E \times 100}{\text { negative Control Group } R E}
\end{gathered}
$$

Larval packet test (LPT). Larvicidal activity of the EO on $R$. (B.) microplus larvae was determined by the Larval Packet Test (LPT). EO was used at concentrations of 25.00, 12.50, 6.25, 3.00, $1.50,0.78,0.39,0.19,0.09,0.04,0.020 .01,0.006,0.003,0.0015$, $0.0007,0.0003,0.00019,0.00009$, and $0.00004 \mathrm{mg} / \mathrm{mL}$. Reading consisted in observing their motility, and those that did not show motility at touch after $24 \mathrm{~h}$ were considered dead (Leite et al. 1995). 
Larval mortality rate (\%) and mean mortality (\%) were calculated according to Equations 3 and 4.

$$
\text { Larval mortality }(\%)=\frac{\text { dead larvae } \times 100}{\text { total larvae }}
$$

$$
\text { Average mortality }(\%)=\frac{1 \text { st repetition }+2 n d \text { repetition }+3 r d \text { repetition }}{3}
$$

Larvicidal activity of Eugenia pyriformis essential oil on the free-living cycle of Rhipicephalus (Boophilus) microplus larvae. Plastic pots $(\mathrm{n}=9), 25 \mathrm{~cm}$ high and $25 \mathrm{~cm}$ in diameter, were filled with $2.2 \mathrm{~kg}$ of soil, previously autoclaved at $121^{\circ} \mathrm{C}$ for $2 \mathrm{~h}$. Each pot was fertilized with $1 \mathrm{~g}$ of N, P, K fertilizer (08-20-10), and six Brachiaria decumbens seeds (Figueiredo et al. 2013) were planted at a depth of $2 \mathrm{~cm}$. Plants were allowed to grow in a greenhouse with daily watering for three months (Araújo et al. 2011). After development, each pot was again fertilized with $1 \mathrm{~g}$ of N, P, K (20-05-20), and the $B$. decumbens leaves were pruned at the height of $40 \mathrm{~cm}$ off the ground. At the edges of the pots, physical barriers of adhesive tape were placed to prevent the larvae from escaping. Then $30 \mathrm{mg}$ of larvae were deposited at the base of each $B$. decumbens seedling. After $24 \mathrm{~h}$, the larvae migrated to the apex of the grass leaves. After that, $5 \mathrm{~mL}$ of a positive control triplicate (commercial solution at $0.000125 \mathrm{mg} / \mathrm{mL}$ containing $0.015 \mathrm{mg} / \mathrm{mL}$ cypermethrin, $0.025 \mathrm{mg} / \mathrm{mL}$ chlorpyrifos and $0.001 \mathrm{mg} / \mathrm{mL}$ citronellal) were sprayed on the grass leaves. Negative control $(2 \%(\mathrm{v} / \mathrm{v})$ aqueous polysorbate-80 solution) and E. pyriformis EO were prepared in a $2 \%(\mathrm{v} / \mathrm{v})$ aqueous polysorbate- 80 solution at the $\mathrm{CL}_{99.9}$ previously established in in vitro tests. The application was concentrated at the apex of the plant, simulating the application of commercial acaricides on pastures. After 24h, the Brachiaria leaves were removed and the dead larvae were counted with the aid of an entomological magnifying glass. The mean number of live larvae in the negative control group was compared with the mean number of live larvae in the treatments. Extract efficacy (\%) was obtained according to Equation 5 (Bittencourt et al. 2003), where: $A=$ mean number of live larvae in the negative control group and $\mathrm{B}=$ mean number of live larvae in the treatment groups.

$$
\operatorname{Efficiency}(\%)=\frac{A-B \times 100}{A}
$$

Anticholinesterase activity of the essential oil. Anticholinesterase activity was determined by the Bioautographic Method described by Marston et al. (2002), with modifications (Yang et al. 2009). Eugenia pyriformis leaf EO was tested at concentrations ranging from 500.00 to $0.18 \mathrm{mg} / \mathrm{mL}$, diluted in methanol. The samples were plotted on aluminum chromatoplates $(10 \times 10 \mathrm{~cm}, 0.2 \mathrm{~mm}$ thick, silica gel 60 F254). After plotting, the plates were dried and an acetylcholinesterase enzyme solution in TRIS buffer was sprayed on them, followed by spraying of an $\alpha$-naphthyl acetate solution. The plates were kept at $37^{\circ} \mathrm{C}$ for $20 \mathrm{~min}$. After that, the chromatoplates were sprayed with Fast Blue B salt colorimetric reagent, resulting in a purple-colored surface. Anticholinesterase activity of the EO was determined by the appearance of white spots after $5 \mathrm{~min}$, demonstrating the inhibitory action of the concentrations evaluated on the enzyme activity, contrasting with the purple color of the colorimetric reagent (Collins et al. 1997). The positive pattern was Temephós ${ }^{\circledR}$ larvicide.

Statistical analysis. The experimental design was completely randomized. Data were processed and submitted to analysis of variance (ANOVA), and differences between arithmetic means and the standard deviation were determined by Tukey's test at $5 \%$ significance level. Lethal concentrations that killed 50\% ( $\left.\mathrm{LC}_{50}\right)$ and 99.9\% ( $\mathrm{LC}_{99.9}$ ) of adult teleogines and larvae and their CIs (5\%) were calculated by Probit analysis (ED 50 Plus 1.0). All tests were performed in triplicate.

\section{RESULTS AND DISCUSSION}

Data on plant material, soil analysis, temperature $\left({ }^{\circ} \mathrm{C}\right)$, rainfall (mm) and relative humidity $(\%)$

Hydrodistillation of dried Eugenia pyriformis leaves yielded $0.023 \% \pm 0.06$ colorless oil. These results are in accordance with those of Stefanello et al. (2009), who found yield of 0.02-0.04\% for fresh leaves in the city of Curitiba, Paraná state, Brazil, collected from October to December 2005. However, Apel et al. (2004), using fresh leaves collected in the state of Rio Grande do Sul, Brazil, in June 1997, found a yield $(0.4 \%)$ higher than that obtained in the present experiment. This difference may have been influenced by seasonality (Morais 2009), as this species is resistant to cold, light frost, and abundant rainfall (Sartori et al. 2010). This information coincides with the meteorological data for the region where the leaves were collected, whose data showed $19.65 \pm 3.62^{\circ} \mathrm{C}$ temperature, $70.86 \pm 44.53 \mathrm{~mm}$ rainfall, and $77.56 \pm 4.87(\%)$ relative humidity.

Density and refractive index found in this study were $0.95 \mathrm{~g} / \mathrm{mL}$ and 1.4835 , respectively. These parameters confirm the identity and detection of essential oil impurities (Instituto Adolfo Lutz 1985). Care during the extraction and storage processes influences the quality of essential oils, as they are unstable in the presence of light, oxygen, heat, moisture, and metals. Thus, it is necessary to perform physicochemical analyses as a way of certifying and maintaining quality (Serafini et al. 2001).

The soil in which E. pyriformis was planted is classified as clayey, acidic ( $\mathrm{pH} 4.13$ ), of low fertility (V\% 24.23), and normality for organic matter (23.19\% C) (Ronquim 2010) (Table 1).

According to Nascimento et al. (1995), the ideal soils for "uvaia" cultivation are clayey neosols or latosols and perfect soil pH is 4.1-5.6. Sartori et al. (2010) consider the pH of 4.5-5.5 as ideal for the cultivation of sedimentary origin and average fertility. Thus, the location where the E. pyriformis of this study was cultivated corroborated the data in the literature regarding the appropriate soil characteristics.

\section{Chemical characterization of the essential oil (EO)}

Thirty-two compounds were identified by GC/MS in the EO extracted in this study. The predominant class was sesquiterpenes: oxygenates $(82.02 \%)$ and hydrocarbons $(17.98 \%)$, with spathulenol (43.65\%) and caryophyllene oxide $(12.17 \%)$ as the most commonly found (Table 2$)$.

Comparison between the chemical composition of the Eugenia pyriformis leaf EO found in the present experiment and those of other studies showed that in Porto Alegre, Rio Grande do Sul state, Brazil, Apel et al. (2004) identified 29 compounds whose main class was sesquiterpenes: hydrocarbons (17.98\%) and oxygenates, $(81.96 \%)$ with predominance of $\alpha$-cadinol $(14.00 \%)$ and $\delta$-cadinene $(12.40 \%)$. In this same context, the study conducted by Stefanello et al. (2009) in Curitiba, Paraná state, Brazil, found 65 compounds whose predominant class was monoterpenes, with limonene $(12.05 \%)$ and $\beta$-pinene 
Table 1. Analysis of pH, base saturation, micro- and macro-nutrients of the soil for cultivation of Eugenia pyriformis

\begin{tabular}{|c|c|c|c|c|c|c|c|c|c|}
\hline \multirow[b]{3}{*}{$\mathrm{pH}\left(\mathrm{CaCl}_{2}\right)$} & \multicolumn{9}{|c|}{$\mathrm{pH}$ and Macronutrients } \\
\hline & \multicolumn{7}{|c|}{$\mathrm{cmol} / \mathrm{dm}^{-3}$} & \multicolumn{2}{|c|}{$\mathrm{mg} \mathrm{dm}^{-3}$} \\
\hline & $\mathrm{Al}^{3+}$ & $\mathrm{H}^{+}+\mathrm{Al}^{3+}$ & $\mathrm{Ca}^{2+}+\mathrm{Mg}^{2+}$ & $\mathrm{K}^{+}$ & & $\mathrm{SB}^{*}$ & CEC* & $\mathrm{P}$ & $\mathrm{C}$ \\
\hline 4.13 & 1.90 & 10.85 & 3.07 & 0.4 & & 3.47 & 14.32 & 4.36 & 23.19 \\
\hline Base saturation & \multicolumn{9}{|c|}{ Micronutrients $\left(\mathrm{cmol} / \mathrm{dm}^{-3}\right)$} \\
\hline $\mathrm{V}(\%)$ & $\mathrm{Fe}$ & $\mathrm{Cu}$ & $\mathrm{Mn}$ & $\mathrm{Zn}$ & B & $S$ & $\mathrm{Ca} / \mathrm{Mg}$ & $\mathrm{Ca} / \mathrm{K}$ & $\mathrm{Mg} / \mathrm{K}$ \\
\hline 24.23 & 46.10 & 6.97 & 120 & 5.59 & 0.30 & 4.73 & 1.26 & 4.27 & 3.4 \\
\hline
\end{tabular}

$\mathrm{SB}=$ sum of bases, $\mathrm{CEC}=$ cation exchange capacity, $\mathrm{V}=$ base saturation, $\mathrm{pH}=\mathrm{pH}$ in $\mathrm{CaCl}_{2}, \mathrm{P}=$ phosphorus, $\mathrm{C}=$ carbon, $\mathrm{Al}^{3+}=$ aluminum, $\mathrm{H}^{+}+\mathrm{Al}^{3+}=$ potential acidity, $\mathrm{Ca}^{2+}=$ calcium, $\mathrm{Mg}^{2+}=$ magnesium, $\mathrm{K}^{+}=$potassium.

Table 2. Chemical composition of Eugenia pyriformis leaf essential oil

\begin{tabular}{|c|c|c|c|c|}
\hline Peak & Compounds $^{\mathrm{a}}$ & $\begin{array}{c}\text { Relative area } \\
(\%)\end{array}$ & RI calculate ${ }^{c}$ & Method identification \\
\hline \multicolumn{5}{|c|}{ Hydrocarbon sesquiterpenes } \\
\hline 1 & $\alpha$-copaene & 1.11 & 1376 & $a, b, c$ \\
\hline 2 & $\beta$-bourbonene & 2.25 & 1388 & $a, b, c$ \\
\hline 3 & $\beta$-elemene & $\mathrm{t}$ & 1390 & $\mathrm{a}, \mathrm{b}, \mathrm{c}$ \\
\hline 4 & $\alpha$-gurjunene & $\mathrm{t}$ & 1409 & $a, b, c$ \\
\hline 5 & $\beta$-caryophylene & 1.49 & 1419 & $a, b, c$ \\
\hline 6 & $\beta$-gurjunene & 0.70 & 1433 & $a, b, c$ \\
\hline 7 & Aromadendrene & 1.40 & 1441 & $a, b, c$ \\
\hline 8 & $\alpha$-humulene & 1.18 & 1454 & $a, b, c$ \\
\hline 9 & Allo-aromadendrene & 2.37 & 1460 & $a, b, c$ \\
\hline 10 & $\alpha$-amorphene & 0.79 & 1484 & $a, b, c$ \\
\hline 11 & Germacrene D & $\mathrm{t}$ & 1485 & $a, b, c$ \\
\hline 12 & Bicyclogermacrene & 1.99 & 1500 & $a, b, c$ \\
\hline 13 & $\alpha$-muurolene & 0.82 & 1500 & $a, b, c$ \\
\hline 14 & $\gamma$-cadinene & 1.06 & 1513 & $a, b, c$ \\
\hline 15 & Cis-calamenene & 0.79 & 1522 & $a, b, c$ \\
\hline 16 & Trans-cadina 1,4 - diene & 0.78 & 1534 & $a, b, c$ \\
\hline 17 & $\alpha$-cadinene & 1.25 & 1538 & $a, b, c$ \\
\hline \multicolumn{5}{|c|}{ Oxygenated sesquiterpenes } \\
\hline 18 & Valerenol & $\mathrm{t}$ & & $a, b, c$ \\
\hline 19 & Spathulenol & 43.65 & 1578 & $a, b, c$ \\
\hline 20 & Caryophylene oxide & 12.17 & 1583 & $a, b, c$ \\
\hline 21 & Viridiflorol & 5.00 & 1592 & $a, b, c$ \\
\hline 22 & Globulol & 1.86 & 1590 & $a, b, c$ \\
\hline 23 & Guaiol & 2.35 & 1560 & $a, b, c$ \\
\hline 24 & Ledol & 2.91 & 1602 & $a, b, c$ \\
\hline 25 & N.i. & 0.03 & & $a, b, c$ \\
\hline 26 & Iso-sphatulenol & 1.55 & 1625 & $a, b, c$ \\
\hline 27 & Epi- $\alpha$-cadinol & 4.29 & 1638 & $a, b, c$ \\
\hline 28 & Allo-aromadendrene epoxide & 1.54 & 1641 & $a, b, c$ \\
\hline 29 & Epi- $\alpha$-muurolol & 4.18 & 1640 & $a, b, c$ \\
\hline 30 & Cariofilla-3,8(13)-dien-5 $\beta$-ol & 0.89 & 1640 & $a, b, c$ \\
\hline 31 & $\alpha$-santalol & 0.57 & 1674 & $a, b, c$ \\
\hline 32 & $\beta$-santalol & 1.00 & 1715 & $a, b, c$ \\
\hline \multicolumn{2}{|c|}{ TOTAL identified } & 99.94 & & \\
\hline \multicolumn{2}{|c|}{ Hydrocarbon sesquiterpenes } & 17.98 & & \\
\hline \multicolumn{2}{|c|}{ Oxygenated sesquiterpenes } & 81.96 & & \\
\hline
\end{tabular}


$(15.60 \%)$ as the most common. The Eugenia pyriformis leaf EO composition in this experiment showed variability compared with the studies by Apel et al. (2004) and Stefanello et al. (2009). Interestingly, the experiments conducted with EO of this species were mainly conducted in the southern Brazil. Although this region presents similar climatic characteristics, differences in EO chemical composition were observed. This variability in EO chemical composition may be associated with the influence of environmental factors such as temperature and humidity, edaphic factors, and genetic variability (Borsato et al. 2007, Gobbo-Neto \& Lopes 2007, Cerqueira et al. 2009). The EO analyzed in this study was obtained from a single species, in the same locality, and under the same conditions. Thus, it is considered that local climatic variations and soil composition (Table 1) contributed to its variability. Biotic and abiotic factors directly influence the chemical composition of essential oils. According to Morais (2009), information on the species used, the vegetative phase of the plant during collection, crop implantation location, soil information, temperature and altitude are fundamental for the correct knowledge of its chemical and biological characteristics.

\section{EO activity on Rhipicephalus (Boophilus) microplus in vitro}

The objective of the present experiment was to verify in which stage of the $R$. (B.) microplus reproductive cycle the EO showed the highest activity. The results of acaricidal activity indicated that Eugenia pyriformis EO, at the tested concentrations, did not significantly promote mortality of engorged females (Fig.1), with $\mathrm{LC}_{50}$ of $1,562.90 \mathrm{mg} / \mathrm{mL}$ and $\mathrm{LC}_{99.9}$ of $2,578.67 \mathrm{mg} / \mathrm{mL}$ (Table 3), i.e., the EO did not act in the first stage of southern cattle tick reproductive cycle, which corresponds to the parasitic life cycle.

Another important step in this experiment was to evaluate whether E. pyriformis essential oil inhibited the hatchability of eggs (Fig.2). The results indicated that, at the concentration of $500.00 \mathrm{mg} / \mathrm{mL}$, the EO provided $54.36 \%$ inhibition, thus evidencing low reproductive efficiency of the tick (64.73\%) (Fig.3).

However, the EO showed higher activity when tested in the free-living cycle, which corresponds to the larval stage (Fig.4), showing $\mathrm{LC}_{50}$ of $0.06 \mathrm{mg} / \mathrm{mL}$ and $\mathrm{LC}_{99.9}$ of $24.60 \mathrm{mg} / \mathrm{mL}$ (Table 3 ).

Effect of the EO on the larvae were expressive because, according to Cheng et al. (2003), good larvicidal agents present $\mathrm{LC}_{50}$ values $<0.10 \mathrm{mg} / \mathrm{mL}$, and the E. pyriformis $\mathrm{EO} \mathrm{LC}_{50}$ found in the present experiment was $0.06 \mathrm{mg} / \mathrm{mL}$ (Table 3). When comparing the LCs between engorged females and larvae, it was evident that the EO was more active on the larvae. The likely explanation for this difference may be associated with the cuticle composition of the larvae and adult females, as tick cuticle is formed by an outer layer, epicuticle (composed of waxes and proteins), and an inner layer, endocuticle (composed of chitin and protein). According to Odhiambo (1982), the lipid layer is observed in $R$. (B.) microplus only from nymph ecdysis and, in greater quantity in the adult tick, in which it is thicker. This difference in cuticle thickness is also explained by Furlong \& Sales (2007), who stated that the increase in the cuticle thickness of engorged females occurs as a result of hormonal stimulation, so that there is no extravasation of their acquired proteins during the blood meal. According to Santos et al. (2015), cuticle thickening

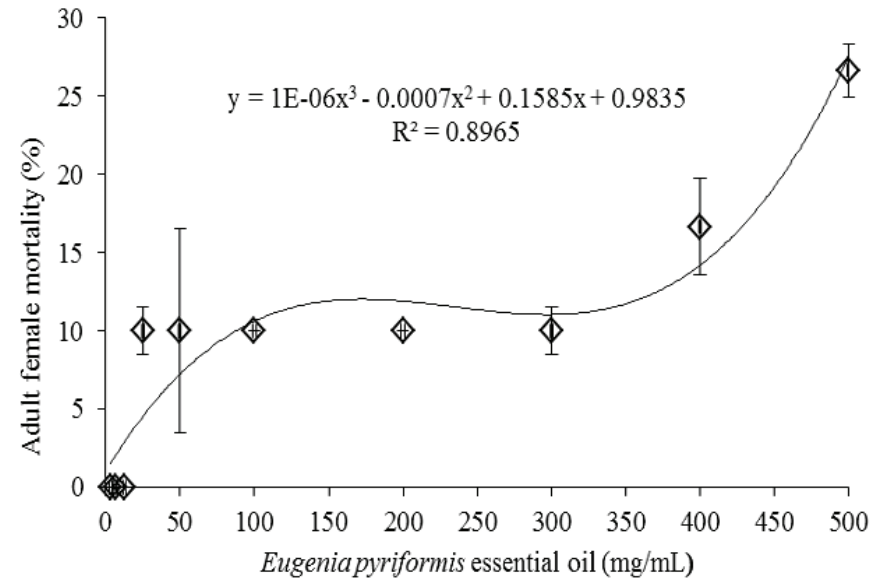

Fig.1. Mortality (\%) of Rhipicephalus (Boophilus) microplus engorged adult females subjected to the adult immersion test (AIT) at different concentrations of Eugenia pyriformis essential oil. Positive control (commercial solution) $=100 \%$ adult female mortality and negative control ( $2 \%$ polysorbate- 80$)=0 \%$ adult female mortality.

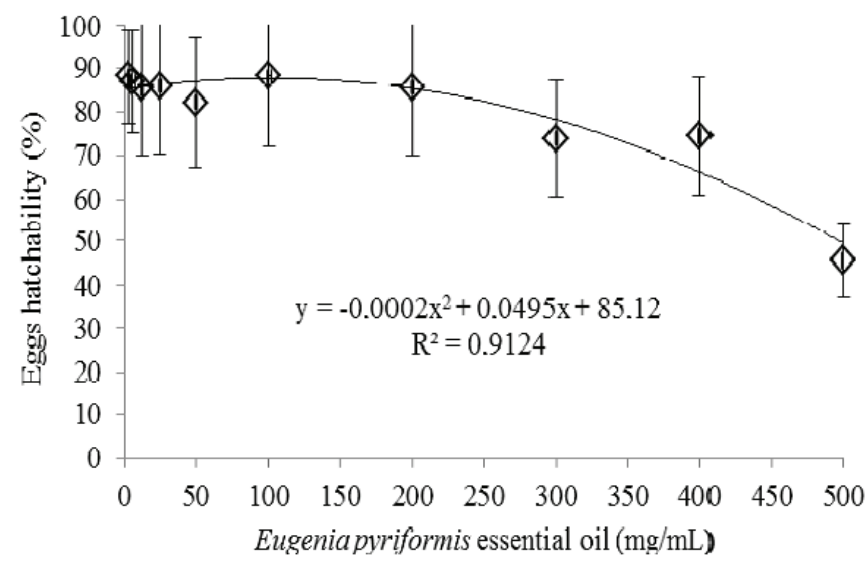

Fig.2. Hatchability of eggs (\%) of Rhipicephalus (Boophilus) microplus subjected to adult immersion test (AIT) at different concentrations of Eugenia pyriformis essential oil. Positive control (commercial solution $)=0 \%$ hatchability of eggs and negative control $(2 \%$ polysorbate-80) $=95.71 \pm 2.17 \%$ hatchability of eggs.

Table 3. Lethal concentrations $\left(\mathrm{LC}_{50}\right.$ and $\left.\mathrm{LC}_{99.9} \mathrm{mg} / \mathrm{mL}\right)$ of Eugenia pyriformis leaf essential oil on adult females and larvae of Rhipicephalus (Boophilus) microplus by Probit analysis

\begin{tabular}{lll}
\hline & \multicolumn{2}{c}{ Rhipicephalus (Boophilus) microplus } \\
\hline & \multicolumn{1}{c}{$\mathrm{CL}_{50}(\mathrm{mg} / \mathrm{mL})$} & \multicolumn{1}{c}{$\mathrm{CL}_{99.9}(\mathrm{mg} / \mathrm{mL})$} \\
\hline Positive control & $0.019 \pm 0.001^{\mathrm{a}}$ & $0.21 \pm 0.01^{\mathrm{a}}$ \\
& $\left(^{*}\right)$ & $\left(^{*}\right)$ \\
Larvae & $0.06 \pm 0.003^{\mathrm{a}}$ & $24.6 \pm 5.74^{\mathrm{a}}$ \\
CI & $(0.057-0.063)$ & $(18.86-30.34)$ \\
Adult females & $1,208.80 \pm 118.80^{\mathrm{b}}$ & $2,538 \pm 238^{\mathrm{b}}$ \\
CI & $(1,111.90-1,305.70)$ & $(2,344-2,733)$
\end{tabular}

Values presented as mean \pm standard deviation. a,b Means followed by same letters in the same column do not statistically differ by Tukey's test at $5 \%$ significance level; $\mathrm{LC}_{50}=$ lethal concentration $50 \%$, $\mathrm{LC}_{99.9}=$ lethal concentration $99.9 \%, \mathrm{CI}=$ confidence interval, Positive control $=$ commercial organophosphorus $(15 \%$ cypermethrin; $25 \%$ chlorpyrifos; $1 \%$ citronellal). 
makes it difficult for EO to penetrate only through joints and natural orifices, leaving the adult tick less vulnerable to poisoning, which makes the lethal dose higher for teleogines compared with larvae.

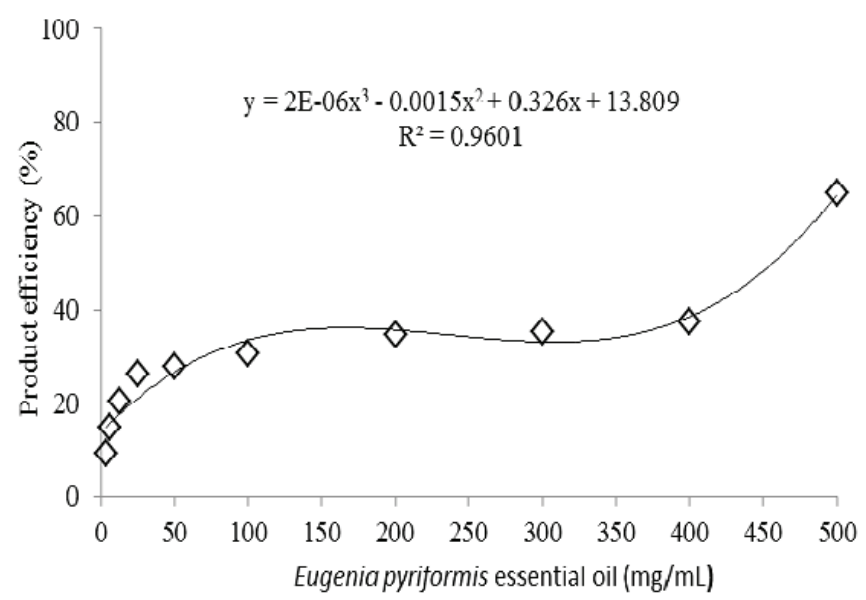

Fig.3. Product efficiency (\%) of Eugenia pyriformis essential oil on Rhipicephalus (Boophilus) microplus. Positive control (commercial solution $)=100 \%$ product efficiency and negative control $(2 \%$ polysorbate-80) $=0 \%$ product efficiency. Means obtained from the equation by Drummond et al. (1973).

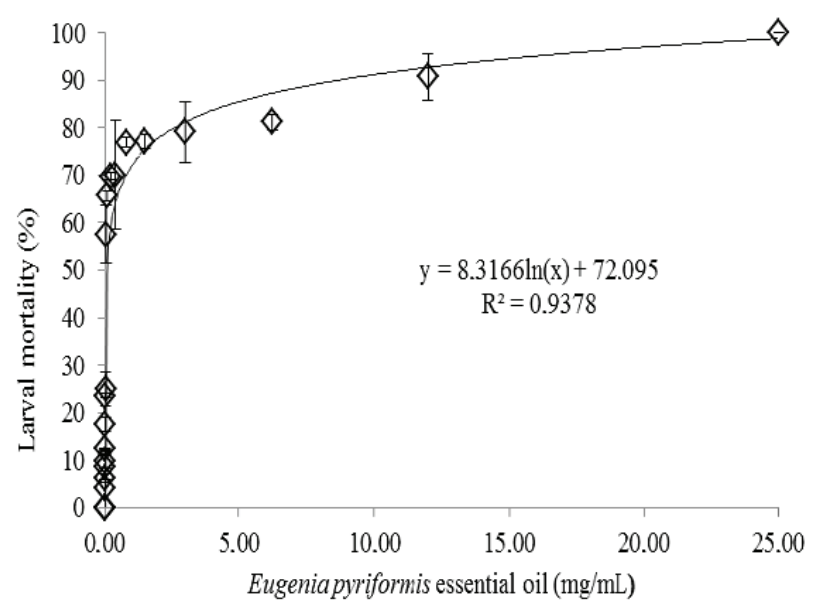

Fig.4. Mortality (\%) of Rhipicephalus (Boophilus) microplus larvae subjected to the larval packet test (LPT) at different concentrations of Eugenia pyriformis essential oil. Positive control (commercial solution $)=100 \%$ larval mortality and negative control $(2 \%$ polysorbate-80) $=0 \%$ larval mortality.

\section{EO activity on Rhipicephalus (Boophilus) microplus under semi-natural conditions}

Another stage of the reproductive cycle of the tick corresponds to the larval free-living cycle. It is an important stage because $95 \%$ of the larvae are distributed in pastures, and only $5 \%$ are parasitizing animals (Powell \& Reid 1982). Thus the $\mathrm{LC}_{99.9}$ of $24.60 \mathrm{mg} / \mathrm{mL}$ (Table 3 ) found for larvicidal activity by the Larval Packet Test was used in the field tests for the tick free-living cycle (Table 4).

Twenty-four hours after EO spraying at $24.60 \mathrm{mg} / \mathrm{mL}$ concentration on tick larvae positioned at the apex of the Brachiaria decumbens leaves, larva mortality of $72.25 \%$ was observed (Table 4).

Some essential oils have been shown to have proven acaricidal activity on $R$. (B.) microplus larvae in in vitro studies (Scoralik et al. 2012). However, there seem to be no reports on the application of E. pyriformis EO for tick control at any stage of the free-living cycle, which is the first to evaluate the activity of EO on $R$. (B.) microplus larvae under semi-natural conditions.

Regarding the application of EO and other substances of plant origin, many in vitro studies have been conducted, but there are still few investigations ex sito, simulating field conditions. Under semi-natural conditions, thymol found in the EO of Lamiaceae and Verbenaceae (Pengelly 2004) plants was tested at a concentration of $10 \mathrm{mg} / \mathrm{mL}$ (LC90 $=9.25 \mathrm{mg} / \mathrm{mL}$ ) in Brachiaria decumbens pots containing of $R$. (B.) microplus larvae, reducing more than $95 \%$ the number of live larvae (Araújo et al. 2015), thus indicating the efficiency of the protocol established by this author.

From the results obtained in the present study, it is possible to conclude that E. pyriformis EO, when applied to $B$. decumbens pots under semi-natural conditions, showed a $72.25 \%$ reduction in tick larvae reproductive efficiency and stability when used in an uncontrolled environment (Table 4).

\section{Anticholinesterase activity of the essential oil (EO)}

Another important aspect within this research was to determine by which mechanism of action the EO acted on southern cattle tick. In conventional southern cattle tick control treatment, it is common to use organophosphate, a class of pesticides that promote the inhibition of the acetylcholinesterase (AchE) enzyme. Despite the high toxicity of these substances, they are widely used in livestock and agriculture, as well as domestically (Worek et al. 2005).

Thus the activity on AchE was evaluated by the Bioautographic Method (Table 5).

The results showed that the EO inhibited the enzyme at a concentration of $3.15 \mathrm{mg} / \mathrm{mL}$, which is superior to the results

Table 4. Larvicidal activity of Eugenia pyriformis leaf essential oil on larvae of Rhipicephalus (Boophilus) microplus by the ex situ test

\begin{tabular}{ccc}
\hline Treatment & Mean number of live larvae & Treatment efficacy (\%) \\
\hline Positive control & $0.00 \pm 0.00^{\mathrm{a}}$ & 100 \\
EO (24.6 mg/mL) & $66.00 \pm 15.51^{\mathrm{a}}$ & 72.25 \\
Negative control & $237.67 \pm 55.19^{\mathrm{b}}$ & 0.00
\end{tabular}

Values presented as mean \pm standard deviation. $a, b$ Means followed by same letters in the same column do not statistically differ by Tukey's Test at $5 \%$ significance level; Positive control = commercial organophosphorus $(15 \%$ cypermethrin, $25 \%$ chlorpyrifos, $1 \%$ citronellal), Negative control $=$ polysorbate- $80(2 \%)$. 
Table 5. Inhibiting activity of acetylcholinesterase enzyme at different concentrations of Eugenia pyriformis leaf essential oil (EO) by the Bioautographic Method

\begin{tabular}{ccc}
\hline \multicolumn{3}{c}{ Acetylcholinesterase inhibitor (AChEI) } \\
\hline $\begin{array}{c}\text { Concentration } \\
(\mathrm{mg} / \mathrm{mL})\end{array}$ & $\begin{array}{c}\text { Eugenia pyriformis } \\
(\text { EO) }\end{array}$ & Positive control \\
\hline 500.00 & + & + \\
400.00 & + & + \\
300.00 & + & + \\
200.00 & + & + \\
100.00 & + & + \\
50.00 & + & + \\
25.00 & + & + \\
12.50 & + & + \\
6.25 & + & + \\
3.15 & + & + \\
0.75 & - & + \\
0.37 & - & + \\
0.18 & - & +
\end{tabular}

$\mathrm{PC}=$ Positive control; commercial organophosphorus (15\% cypermethrin, $25 \%$ chlorpyrifos, $1 \%$ citronellal); +++ strong inhibition, ++ moderate inhibition, + weak inhibition of acetylcholinesterase enzyme; (-) absence of inhibition; EO = essential oil.

found in the in vivo larvae test $\left(\mathrm{LC}_{999} 24.60 \mathrm{mg} / \mathrm{mL}\right)$. This difference may be explained by the absence of physiological conditions that interfere with biochemical reactions in vivo, because the Bioautographic Method is performed in a controlled environment with all pre-established conditions, without interference of cell wall permeability, absorption characteristics of molecules, as well as solubility in hydrophilic and lipophilic media inherent in living beings (Benson 2005, Brain et al. 2007).

Molecules capable of inhibiting or reactivating the AChE enzyme are potential substitutes for organophosphates. Success in developing products of these classes depends on the efficiency and practicality of the tests employed to evaluate AchE activity (Araújo et al. 2016).

\section{CONCLUSIONS}

Eugenia pyriformis Cambess leaf essential oil (EO) presented sesquiterpenes as the predominant class, with spathulenol and caryophyllene oxide as major compounds.

In in vitro tests, the EO was active against Rhipicephalus (Boophilus) microplus southern cattle tick larvae at $\mathrm{LC}_{99.9}$ of $24.6 \mathrm{mg} / \mathrm{mL}$. When tested under semi-natural conditions (ex situ), the EO showed a $72.25 \%$ reduction in tick larvae reproductive efficiency and stability when applied in an uncontrolled environment. The mechanism of action by which the EO killed the larvae was inhibition of the acetylcholinesterase enzyme at a concentration of $3.15 \mathrm{mg} / \mathrm{mL}$, thus indicating presence molecules with biocidal potential in the E. pyriformis leaf EO.

Acknowledgments. - The authors are grateful to "Universidade Paranaense" (Unipar), "Centro Universitário de Maringá” (UNI-Cesumar), "Coordenação de Aperfeiçoamento de Pessoal de Nível Superior" (CAPES), and "Conselho Nacional de Desenvolvimento Científico e Tecnológico" (CNPq) for the fellowships and financial support provided to this study.
Conflict of interest.- The authors have no conflicts of interest to declare.

\section{REFERENCES}

Adams R.P. 2012. Identification of essential oil components by gas chromatography/mass spectroscopy. 4th ed. Allured Publishing Corporation, Carol Stream, IL. 804p.

Alves R.H., Mendonça I.L., Dos Santos J.P. \& De Souza J.S.N. 2014. Ação do extrato etanólico de Eucalyptus sp. sobre fêmeas ingurgitadas e larvas de Rhipicephalus (Boophilus) microplus. Boletim Inform. Geum 5(2):94.

Apel M.A., Sobral M., Schapoval E.E., Henriques A.T., Menut C. \& Bessière J.M. 2004. Chemical composition of the essential oils of Eugenia beaurepaireana and Eugenia pyriformis: section dichotomae. J. Essential Oil Res. 16(3):191192. <http://dx.doi.org/10.1080/10412905.2004.9698694>

Araújo A.S.A., Guimarães L.R.G., Lopes G. \& Campos M.L. 2011. Fitorremediação de solos contaminados com arsênio (As) utilizando braquiária. Ciênc. Agrotec. 35(1):84-91. <http://dx.doi.org/10.1590/S1413-70542011000100010>

Araújo C.R.M., Santos V.D.A. \& Gonsalves A.A. 2016. Acetilcolinesterase-AChE: uma enzima de interesse farmacológico. Revta Virtual Quím. 8(6):18181834. <http://dx.doi.org/10.21577/1984-6835.20160122>

Araújo L.X., Novato T.P.L., Zeringota V., Matos R.S., Senra T.O.S., Maturano R., Prata M.C.A., Daemon E. \& Monteiro C.M.O. 2015. Acaricidal activity of thymol against larvae of Rhipicephalus microplus (Acari: Ixodidae) under semi-natural conditions. Parasitol. Res. 114(9):3271-3276. <http://dx.doi. org/10.1007/s00436-015-4547-3><PMid:26040843>

Armstrong L., Duarte M.R. \& Miguel O.G. 2012. Morpho-anatomy of the leaf and stem of Eugenia pyriformis. Brazilian J. Pharmacogn. 22(3):475-481. <http://dx.doi.org/10.1590/S0102-695X2012005000022>

Benson H.A.E. 2005. Transdermal drug delivery: penetration enhancement techniques. Curr. Drug Delivery 2(1):23-33. <http://dx.doi. org/10.2174/1567201052772915> <PMid:16305405>

Bittencourt V.R.E.P., Bahiense T.C., Fernandes E.K. \& Souza E.J. 2003. Avaliação da ação in vivo de Metarhizium anisopliae (Metschnikoff, 1879) Sorokin, 1883 aplicado sobre Brachiaria decumbens infestada com larvas de Boophilus microplus (Canestrini, 1887) (Acari: Ixodidae). Revta Bras. Parasitol. Vet. 12(1):38-42.

Borsato A.V., Doni-Filho L., Côcco L.C. \& Paglia E.C. 2007. Rendimento e composição química do óleo essencial da camomila (Chamomilla recutita (L.) Rauschert) submetida à secagem à $70^{\circ} \mathrm{C}$. Semina, Ciênc. Agrárias 28(4):635-644.

Brain K.R., Green D.M., Lalko J. \& Api A.M. 2007. In-vitro human skin penetration of the fragrance material geranyl nitrile. Toxicol. In Vitro 21(1):133-138. <http://dx.doi.org/10.1016/j.tiv.2006.08.005><PMid:17045775>

Campos R.N.D.S., Bacci L., Araújo A.P.A., Blank A.F., Arrigoni-Blank M.D.F., Santos G.R.D.A. \& Roner M.N.B. 2012. Óleos essenciais de plantas medicinais e aromáticas no controle do carrapato Rhipicephalus microplus. Arch. Zootec. 61(R):67-78.

Cerqueira M.D.D., Marques E.D.J., Martins D., Roque N.F., Cruz F.G. \& Guedes M.L.D.S. 2009. Variação sazonal da composição do óleo essencial de Myrcia salzmannii Berg. (Myrtaceae). Quím. Nova 32(6):1544-1554. <http:// dx.doi.org/10.1590/S0100-40422009000600035>

Chagas A.C.S., Passos W.M., Prates H.T., Leite R.C., Furlong J. \& Fortes I.C.P. 2002. Efeito acaricida de óleos essenciais e concentrados emulsionáveis de Eucalyptus spp. em Boophilus microplus. Braz. J. Vet. Res. Anim. Sci. 39(5):247-253. <http://dx.doi.org/10.1590/S1413-95962002000500006>

Cheng S.S., Chang H.T., Chang S.T., Tsai K.H. \& Chen W.J. 2003. Bioactivity of selected plant essential oils against the yellow fever mosquito Aedes Aegypti larvae. Bioresour. Technol. 89(1):99-102. <http://dx.doi.org/10.1016/ S0960-8524(03)00008-7><PMid:12676507>

Clemente M.A., Monteiro C.M.O., Scoralik M.G., Gomes F.T., Prata M.C.A. \& Daemon E. 2010. Acaricidal activity of the essential oils from Eucalyptus 
citriodora and Cymbopogon nardus on larvae of Amblyomma cajennense (Acari: Ixodidae) and Anocentor nitens (Acari: Ixodidae). Parasitol. Res. 107(4):987-992. <http://dx.doi.org/10.1007/s00436-010-1965-0> $<$ PMid:20640444>

Collins C.H., Pezzin S.H., Rivera J.F.L., Bonato P.S., Windmôller C.C., Archundia C. \& Collins K.E. 1997. Liquid chromatographic separation of aqueous species of $\mathrm{Cr}\{\mathrm{VI}$ ) and $\mathrm{Cr}(\mathrm{lll})$. J. Chromatography 789(1-2):469-478. <http://dx.doi. org/10.1016/S0021-9673(97)00676-6>

Da Silva A., Spricigo P., Purgatto E., De Alencar S., Sartori S. \& Jacomino A. 2019. Chemical composition, nutritional value and bioactive compounds in six uvaia accessions. Food Chem. 294:547-556. <http://dx.doi.org/10.1016/j. foodchem.2019.04.121><PMid:31126498>

De Assis C.P., Gondim Junior M.G., De Siqueira H.A. \& Da Câmara C.A. 2011. Toxicity of essential oils from plants towards Tyrophagus putrescentiae (Schrank) and Suidasia pontifica Oudemans (Acari: Astigmata). J. Stored Prod. Res. 47(4):311-315.<http://dx.doi.org/10.1016/j.jspr.2011.04.005>

De Assis L.T.C., Montanari R.M., Fernandes S.A., De Oliveira Monteiro C.M., Senra T.D.O.S., Zeringota V. \& Daemon E. 2015. Chemical composition and acaricidal activity of the essential oil of Baccharis dracunculifolia De Candole (1836) and its constituents nerolidol and limonene on larvae and engorged females of Rhipicephalus microplus (Acari: Ixodidae). Exp. Parasitol. 148:24-29. <http://dx.doi.org/10.1016/j.exppara.2014.10.011> $<$ PMid:25448290>

De Carvalho T.B. \& De Zen S. 2017. A cadeia de pecuária de corte no Brasil: evolução e tendências. Revta iPecege 3(1):85-99.

De Monteiro C.M., Maturano R., Daemon E., Catunda-Junior F.E.A., Calmon F., De Souza S.T. \& De Carvalho M.G. 2012. Acaricidal activity of eugenol on Rhipicephalus microplus (Acari: Ixodidae) and Dermacentor nitens (Acari: Ixodidae) larvae. Parasitol. Res. 111(3):1295-1300. <http://dx.doi. org/10.1007/s00436-012-2964-0> <PMid:22622689>

De Souza C.A.C., De Barros L.D., Cotinguiba F., Furlan M., Giglioti R., De Sena Oliveira M.C. \& Bizzo H.R. 2012. In vitro efficacy of plant extracts and synthesized substances on Rhipicephalus (Boophilus) microplus (Acari: Ixodidae). Parasitol. Res. 110(1):295-303. <http://dx.doi.org/10.1007/ s00436-011-2488-z><PMid:21695568>

Drummond R.O., Ernest S.E., Trevino J.L., Gladney W.J. \& Grhham O.H. 1973. Boophilus annulatus and Boophilus microplus (Acarine: Ixodidae) in natural and experimental conditions. Folia Parasitol. 37:331-336.

FAO 2004. Ticks, Acaricide resistance: diagnosis management and prevention. Module 1, Guidelines Resistance Management and Integrated Parasite Control in Ruminants, Food and Agriculture Organization of the United Nations, FAO Animal Production and Health Division, Rome, p.25-77.

Farmacopeia Brasileira. 1988. Farmacopeia Brasileira. 4ª ed. Atheneu, São Paulo.

Ferrarini S.R., Duarte M.O., Da Rosa R.G., Rolim V., Eifler-Lima V.L., Von Poser G. \& Ribeiro V.L.S. 2008. Acaricidal activity of limonene, limonene oxide and $\beta$-amino alcohol derivatives on Rhipicephalus (Boophilus) microplus. Vet. Parasitol. 157(1/2):149-153.<http://dx.doi.org/10.1016/j. vetpar.2008.07.006><PMid:18755549>

Figueiredo C.C., Resck D.V.S., Carneiro M.A.C., Ramos M.L.G. \& Sá J.C.M. 2013. Stratification ratio of organic matter pools influenced by management systems in a weathered Oxisol from a tropical agro-ecoregion in Brazil. Soil Res. 51(2):133-141. <http://dx.doi.org/10.1071/SR12186>

Furlong J. \& Sales R.O. 2007. Controle estratégico de carrapatos no bovino de leite: uma revisão. Revta Bras. Hig. Sanidade Anim. 1(2):44-72. <http:// dx.doi.org/10.5935/1981-2965.20070009>

Gobbo-Neto L. \& Lopes N.P. 2007. Plantas medicinais: fatores de influência no conteúdo de metabólitos secundários. Quím. Nova. 30(2):374-381. <http://dx.doi.org/10.1590/S0100-40422007000200026>

Gomes G.A., Monteiro C.M.O., Senra T.O.S., Zeringota V., Calmon F., Matos R.S., Daemon E., Gois R.W.S., Santiago G.M.P. \& de Carvalho M.G. 2012. Chemical composition and acaricidal activity of essential oil from Lippia sidoides on larvae of Dermacentor nitens (Acari: Ixodidae) and larvae and engorged females of Rhipicephalus microplus (Acari: Ixodidae). Parasitol. Res. 111(6):2423-2430.<http://dx.doi.org/10.1007/s00436-012-31019> <PMid:22983219>

Grisi L., Leite R.C., Martins J.R.D.S., Barros A.T.M., Andreotti R., Cançado P.H.D., León A.A.P., Pereira J.B. \& Villela H.S. 2014. Reassessment of the potential economic impact of cattle parasites in Brazil. Revta. Bras. Parasitol. 23(2):150-156. <http://dx.doi.org/10.1590/S1984-29612014042> $<$ PMid:25054492>

Instituto Adolfo Lutz. 1985. Normas Analíticas do Instituto Adolfo Lutz: métodos químicos e físicos para análise de alimentos. $3^{\underline{a}} \mathrm{ed}$. Vol.1. IMESP, São Paulo. 1020p.

Leite R.C., Labruna M.B., Oliveira P.R., Monteiro A.M.F. \& Caetano Júnior J. 1995. In vitro susceptibility of engorged females from different populations of Boophilus microplus to commercial acaricides. Revta Bras. Parasitol. Vet. 4(2):283-294.

Marston A., Kissling J. \& Hostettmann K. 2002. A rapid TLC bioautographic method for the detection of acetylcholinesterase and butyrylcholinesterase inhibitors in plants. Phytochem. Anal. PCA 13(1):51-54.<PMid:11899607>

Mendes M.C., Duarte F.C., Martins J.R., Klafke G.M., Fiorini L.C. \& Barros A.T.M.D. 2013. Characterization of the pyrethroid resistance profile of Rhipicephalus (Boophilus) microplus populations from the states of Rio Grande do Sul and Mato Grosso do Sul, Brazil. Revta Bras. Parasitol. Vet. 22(3):379-384. <http://dx.doi.org/10.1590/S1984-29612013000300010> $<$ PMid:24142169>

Morais L.A.S. 2009. Influência dos fatores abióticos na composição química dos óleos essenciais. Horticult. Bras., Brasília, 27(2):S3299-S3302.

Nascimento V.M., Xavier A.A., Corrêa L.S. \& Valério Filho W.V. 1995. Physical and chemical characteristics of the fruit of native's species on the Brazilian cerrado. Acta Hortic. (370):113-116. <http://dx.doi.org/10.17660/ ActaHortic.1995.370.18>

Odhiambo T.R. 1982. Current Themes in Tropical Science: physiology of ticks. Pergamon, Oxford. 508p.

Omolo M.O., Okinyo D., Ndiege I.O., Lwande W. \& Hassanali A. 2004. Repellency of essential oils of some Kenyan plants against Anopheles gambiae. Phytochemistry 65(20):2797-2880. <http://dx.doi.org/10.1016/j. phytochem.2004.08.035><PMid:15474566>

Pengelly A. 2004. The Constituents of Medicinal Plants: an introduction to the chemistry and therapeutics of herbal medicine. 2 nd ed. Allen and Unwin, Austrália. 184p.

Pereira S.G., Nascimento Júnior J.R.S., Lima A.D.S., Costa Junior L.M., Guilhon G.S.P. \& Santos L.D.S. 2015. Ação carrapaticida sobre Rhipicephalus microplus dos extratos, frações e compostos obtidos da espécie Lecythis lurida (Lecythidaceae). Biotemas 28(4):119-130. <http://dx.doi.org/10.5007/21757925.2015v28n4p119>

Powell R.T. \& Reid T.J. 1982. Project tick control. Queensland Agricult. J. 108:279-300.

Ramírez C., Ibarra F., Pérez H.I., Manjarrez N., Salgado H.J. \& Ortega L. 2016. Assessment and determination of LC50 of carvacrol and salicylic acid analogues with acaricide activity in larvae and adult ticks of Rhipicephalus (Boophilus) microplus. Parasite Epidemiol. Control 1(2):72-77. <http:// dx.doi.org/10.1016/j.parepi.2016.02.006><PMid:29988173>

Ronquim C.C. 2010. Conceitos de fertilidade do solo e manejo adequado para as regiões tropicais. 8o Boletim de Pesquisa e Desenvolvimento (Infoteca-E), Embrapa Monitoramento por Satélite, Campinas. 26p.

Santos T.R.B., Castro N.Á., Bretanha L.C., Schuch L.F.D., Freitag R.A. \& Nizoli L.Q. 2015. In vitro study of the effectiveness of citronella (Cymbopogon wynterianus) on the cattle tick Rhipicephalus (Boophilus) microplus. Sci. Anim. Health 3:135-149. <http://dx.doi.org/10.15210/sah.v3i1.4765>

Sartori S., Donadio L.C., Martins A.B.G. \& Moro F.V. 2010. Uvaia. Funep, Jaboticabal. 32p. 
Scoralik M.G., Daemon E., De Oliveira Monteiro C.M. \& Maturano R. 2012. Enhancing the acaricide effect of thymol on larvae of the cattle tick Rhipicephalus microplus (Acari: Ixodidae) by solubilization in ethanol. Parasitol. Res. 110(2):645-648. <http://dx.doi.org/10.1007/s00436-0112539-5> <PMid:21779863>

Serafini L.A., Barros N.M. \& Azevedo J.L. 2001. Biotecnologia na Agricultura e na Agroindústria. Agropecuária, Guaíba. 433p.

Silva A.P.G.D., Tokairini T.D.O., Alencar S.M. \& Jacomino A.P. 2018. Characteristics of the fruits of two uvaia populations grown in Salesópolis, SP, Brazil. Revta Bras. Fruticultura 40(2):e-511. <http://dx.doi.org/10.1590/0100 29452018511>

Simões C.M. \& Spitzer V. 2002. Farmacognosia da Planta ao Medicamento. 3 a ed. Universidade Federal do Rio Grande do Sul, Porto Alegre, p.397-425.

Souza A.M.D. 2013. Avaliação do potencial antimicrobiano de Eugenia pyriformis Cambess., Myrtaceae e estudo da associação sinérgica com agentes antibacterianos e antifúngicos de uso clínico. Master's Thesis, Universidade Federal do Paraná, Curitiba. 120p.

Stefanello M.E., Wisniewski Junior A., Simionatto E.L. \& Cervi A.C. 2009. Chemical composition and seasonal variation of essential oils of Eugenia pyriformis (Myrtaceae). Latin Am. J. Pharmacy 28(3):449-453.
Stieven A.C., Moreira J.J.S. \& Silva C.F. 2009. Essential oils of uvaia (Eugenia pyriformis Cambess): evaluation of the microbiologycal and antioxidant activities. Eclética Quím. 34(3):7-16. <http://dx.doi.org/10.1590/S010046702009000300001>

Valente P.P., Amorim J.M., Castilho R.O., Leite R.C. \& Ribeiro M.F.B. 2014. In vitro acaricidal efficacy of plant extracts from Brazilian flora and isolated substances against Rhipicephalus microplus (Acari: Ixodidae). Parasitol. Res. 113(1):417-423. <http://dx.doi.org/10.1007/s00436-013-3670-2> <PMid:24221889>

Worek F., Koller M., Thiermann H. \& Szinicz L. 2005. Diagnostic aspects of organophosphate poisoning. Toxicology. 214(3):182-189. <http://dx.doi. org/10.1016/j.tox.2005.06.012> <PMid:16051411>

Yang Z., Zhang X., Duan D., Song Z., Yang M. \& Li S. 2009. Modified TLC bioautographic method for screening acetylcholinesterase inhibitors from plant extracts. J. Separation Sci. 32(18):3257-3259. <http://dx.doi. org/10.1002/jssc.200900266> <PMid:19697313>

Zaman M.A., Iqbal Z., Abbas R.Z., Khan M.N., Muhammad G., Younus M. \& Ahmed S. 2012. In vitro and in vivo acaricidal activity of a herbal extract. Vet. Parasitol. 186(3/4):431-436. <http://dx.doi.org/10.1016/j. vetpar.2011.11.018> <PMid:22305296> 